\title{
Sports insurance and national governing bodies
}

\author{
Lyn Jones BSc, MB BS ${ }^{1}$ and Michael McCabe FRCSI, FRCS(Ed) ${ }^{\mathbf{2}}$ \\ ${ }^{1}$ Senior House Officer, Accident and Emergency Department, Cardiff Royal Infirmary, Cardiff, UK \\ 2 Senior Registrar, Accident and Emergency Department, Cardiff Royal Infirmary, Cardiff, UK
}

A postal survey was conducted of the attitudes and advice of Welsh governing bodies of amateur sports and their Cardiff-based clubs towards personal sports insurance. Information on 36 of the 39 sports surveyed $(92 \%)$ was sufficient for analysis. Twenty-two of these 36 sports (61\%) organized insurance at a national level, one at club level $(3 \%)$ and $13(36 \%)$ provided no insurance advice. Only 12 sports (33\%) insisted on mandatory insurance cover. Many sportsmen and women are left to search for an appropriate insurance cover themselves or remain uninsured. Owing to the lack of advice in $36 \%$ of cases it was decided to survey Cardiff-based insurance brokers to establish what type of policy they would recommend. Only $41 \%$ of the brokers were able to offer a suitable policy. Club policies recommended by the Central Council for Physical Recreation provide individuals with the same sports cover (but at a lower premium) as is available from a personal accident policy. However, cover is somewhat inadequate and may provide a false sense of security. Sports with mandatory sports insurance are not necessarily those with the highest risk of disabling injury.

Keywords: Sports, insurance

Injuries in sport are the cause of $7-10 \%$ of the workload of accident departments in the $\mathrm{UK}^{1}$. They lead to considerable national, economic and health problems as many of those injured are in permanent employment. In 1988 there were 82 deaths in England and Wales resulting from sporting activities (Table 1$)^{2}$. Most sports injuries are relatively minor in nature, necessitating absence from work of less than 2 weeks ${ }^{3}$. However, the potential for more serious injury is inherent in sporting activity because the body is being stretched to its limit and safety is not at the forefront of the competitor's mind. In 1985, 17\% of adults in the UK regularly took part in at least one outdoor sport with the highest participation rates being amongst students $(41 \%)$ and professional classes $(27 \%)^{4}$.

Several studies have shown that sporting injuries may be a cause of significant morbidity and mortality. A UK review of neurosurgical unit admissions showed that $(2.7 \%)$ were due to sports, most

Address for correspondence: Michael McCabe, Accident and Emergency Department, Cardiff Royal Infirmary, Newport Road, Cardiff CF2 1SZ, UK

(C) 1991 Butterworth-Heinemann Ltd.

0306-3674/91/010021-03
Table 1. Fatal accidents (except by drowning) occurring in England and Wales during sporting and leisure activities $1988^{2}$

\begin{tabular}{lcl}
\hline Category & No. dead & Largest sub-category \\
\hline Horse-riding & 16 & Unspecified, 8 \\
Motor sports & 12 & Motor-cycle racing, 3 \\
Mountaineering & 12 & Mountain climbing, 7 \\
Water sports & 8 & Diving, 3 \\
Air sports & 8 & Aerobatics, 4 \\
Outdoor sports & 6 & Mountain/fell walking, 4 \\
Cycling & 3 & - \\
Ball games & 3 & Football, 2 \\
Angling & 1 & - \\
Other & 13 & Weightlifting, 2 \\
\hline
\end{tabular}

frequently golf, rugby, horse-riding, soccer and shooting ${ }^{5}$. A review of 1447 spinal fractures treated in Edmonton Alberta noted that $14 \%$ were due to sports injury, especially diving, winter sports, horse-riding, parachuting and motor-cycling ${ }^{6}$. In one ophthalmic unit sports-related ocular trauma accounted for $23 \%$ of all ocular injuries and 50\% of all admissions with hyphaema ${ }^{7}$. The main sporting causes of eye injury in America were baseball, tennis and other racket sports, football, basketball and golf ${ }^{8}$.

Between various sports there is extreme variation in the risk of disablement incurred by participants. Any regular sportsperson takes some degree of risk. In the UK the National Health Service and the Department of Social Security ensure 'life support' on a short-term and long-term basis, respectively, if disablement occurs. However, the effect of disablement upon earning power may greatly reduce the standard of living of the injured person. In countries where there is no national health service the majority of people, whether they participate in sport or not, have some form of personal accident insurance. In the UK most life assurance policies do not cater for long-term disability. Most personal accident policies in the UK do provide a lump sum payment in the event of personal disablement or death, and/or weekly benefit in the even of temporary disablement. Private hospital fees are generally not covered nor are dental or physiotherapy costs. The latter services, which may be essential to the sportsman, may be difficult to obtain quickly on the NHS.

This study aimed to assess whether the governing bodies of amateur sports in Wales and their affiliated Cardiff-based clubs provide adequate insurance advice for their members. 


\section{Methods}

A list of the governing bodies of sport was obtained from the Sports Council for Wales. Thirty-nine with adult amateur members were selected for study. A list of Cardiff-based clubs was obtained from each of the governing bodies by telephone enquiry: 36 of the 39 governing bodies had affiliated clubs which were based in Cardiff. The first local club on each list was selected for study. A postal questionnaire was sent to all the selected clubs and associations in November 1989. A reminder was sent to those who had not replied in January 1990.

All 34 insurance brokers listed in the 1989 Cardiff edition of the classified telephone directory were contacted by telephone and asked for information about personal accident policies available to an individual sportsperson. Advice about sports insurance in general was also sought from the Central Council for Physical Recreation (CCPR) and the Sports Council for Wales. Details of the CCPR recommended policy were obtained.

\section{Results}

Replies were received from representatives of 36 of the 39 sports selected (92\%). Thirty-one out of 39 Welsh Associations replied (79\%), and 22 out of 36 local clubs $(61 \%)$. Where information was duplicated it was cross checked and found to be correct. Twenty-two sports $(61 \%)$ had insurance policies negotiated and recommended by their national governing bodies. In $15(68 \%)$ of these 22 sports the recommended policies were 'taken out' by affiliated clubs on behalf of their members and for the other

Table 2. Organization $(\mathrm{O})$ and level of implementation (l) of personal accident policies for various sports in Wales

\begin{tabular}{|c|c|c|c|}
\hline \multicolumn{2}{|c|}{ O: National } & \multirow{2}{*}{$\frac{\text { O: Club }}{\text { I: Club }}$} & \multirow{2}{*}{$\frac{\text { O: Individual }}{\text { I: Individual }}$} \\
\hline I: Club & I: Individual & & \\
\hline $\begin{array}{l}\text { Sports with man } \\
\text { Athletics } \\
\text { Boxing } \\
\text { Fencing } \\
\text { Gymnastics } \\
\text { Judo } \\
\text { Motor-cycling } \\
\text { Rugby }\end{array}$ & $\begin{array}{l}\text { ory insurance pc } \\
\text { Canoeing } \\
\text { Cycling } \\
\text { Karate }\end{array}$ & Lacrosse & Motoring \\
\hline $\begin{array}{l}\text { Sports with opti } \\
\text { Badminton } \\
\text { Baseball } \\
\text { Cricket } \\
\text { Football } \\
\text { Lawn tennis } \\
\text { Netball } \\
\text { Shooting } \\
\text { Water-skiing }\end{array}$ & $\begin{array}{l}\text { I insurance poli } \\
\text { Bowling } \\
\text { Hang-gliding } \\
\text { Subaqua } \\
\text { Yachting }\end{array}$ & & $\begin{array}{l}\text { Caving } \\
\text { Golf } \\
\text { Hockey } \\
\text { Horse-riding } \\
\text { Ice-skating } \\
\text { Orienteering } \\
\text { Rowing } \\
\text { Squash } \\
\text { Surfing } \\
\text { Swimming } \\
\text { Table tennis } \\
\text { Volley ball }\end{array}$ \\
\hline
\end{tabular}

No information was obtained on angling, mountaineering and weight lifting
Table 3. Sports specifically excluded from policies available to individual applicants

\begin{tabular}{lc}
\hline & No. policies \\
\hline Aerial sports (including parachuting) & 5 \\
Racing (either driving or riding) & 5 \\
Mountaineering & 3 \\
Winter sports & 3 \\
Potholing & 2 \\
Hunting & 2 \\
Motor-cycling & 2 \\
Rugby & 1 \\
Gaelic football & 1 \\
American football & 1 \\
Soccer & 1 \\
Hockey & 1 \\
\hline
\end{tabular}

seven $(32 \%)$ sports the recommended policies were taken out by individual affiliated members (Table 2). Lacrosse had an insurance recommended by the local club which was mandatory. (Therefore 23 sports in total had insurance organized at some level.) For 16 (69\%) of the 23 sports which provided information, details were included in their reply about the amount of benefit paid. Only 12 of the 36 sports (33\%) had governing bodies which made a personal accident policy mandatory for all affiliated individuals.

Insurance policies taken out at club level, including that recommended by the CCPR, provide benefits of up to $£ 50000$ lump sum for an annual preimium of under $£ 1$ per club member (amount depending on sport and a minimum of 50 members). There are no sporting exclusions, but these policies do not cover the individual for injuries incurred during other everyday non-sporting activities. Sports kits, physiotherapy and dental fees are optional extras but may double the premium.

Fourteen of the 34 insurance brokers provided information about suitable insurance policies $(41 \%)$; the total number of policies recommended was eight. These policies are not particularly designed for sports cover but are personal accident policies for everyday living which may be extended to cover sporting activity. The premium required depended on the occupational group of the insured individual in five of the policies, and two further policies were only available to professional occupations. The premium also depended on the number of weeks immediately after injury during which the insured person would agree not to claim ('excess'). The monthly cost of premiums ranged from $£ 0.91$ to $£ 10.50$. Some sports were specifically exlcuded from these policies (Table 3).

\section{Discussion and conclusions}

Injury in sport is common but few individuals are adequately insured. This study shows that despite recommendations from the CCPR there is little consensus between governing bodies of amateur sports in Wales on providing guidelines about insurance policies for sports club members. Only $61 \%$ of sports surveyed had any national organization of insurance, and these 22 sports recommended 
policies with widely different levels of cover. Only six of these policies had benefits of $£ 10000$ or more for permanent disablement, and for two of these (athletics and motor-cycling) benefits were only payable for injuries incurred at recognized events or competitions but not during training. A sum of less than $£ 10000$ for permanent disablement is obviously inadequate. Under half (ten of 22) of the recommended policies were made mandatory by the national governing bodies and over half (12 of 22) optional. Some of the sports with optional insurance appear to be more dangerous than those with mandatory insurance (e.g. hang-gliding optional but cycling mandatory).

For 13 sports, insurance was organized neither at national nor at club level despite one (motoring) having mandatory insurance rules. This leaves the responsibility with individual sports club members to find a suitable policy. Information about personal accident policies suitable for a sportsperson was not readily available from insurance brokers. The policies eventually suggested varied widely in levels of cover and premiums payable. Comparisons between such different policies are difficult. The policy recommended by the CCPR appears to offer comparatively good value for money. However, as only $£ 2000$ death benefit is paid there may be a false sense of security. It was noted that $32 \%$ of insurance policies negotiated and recommended by sports governing bodies were implemented by the individual rather than the club. This leads to the possibility of failure to keep premium payments up to date, which could be circumvented by including the premium in the club membership fee. Club bloc subscription is recommended by the CCPR recommended policy to ensure that all members are automatically insured. The problem with such sports-specific policies is that they only cover the client whilst engaged in sports-related activities. There are no benefits payable for injury occurring at work or elsewhere.

Many people will continue to think that insurance cover for everyday living is an unncessary expense. We feel it would be a responsible action of the national governing bodies of sports to make insurance mandatory at club level. This would provide support in the event of sports-related disablement for members who would not otherwise be insured. We believe that all governing bodies of sports for Wales should organize a suitable and adequate insurance policy to be taken out at club level on behalf of members and that the premium be included in the club membership fee. At present only a handful of sports, seven of $36(19 \%)$, have such a policy.

\section{References}

1 Macnicol MF. The torn anterior cruciate ligament. J R Coll Surg Edinb 1989; 34 Suppl; S4-11.

2 Fatal accidents occurring during sporting and leisure activities. 1988 Registrations. Office of Population Census Studies. London: HMSO, 1989. DH4 89/4.

3 Sandelin J, Kiviluoto O, Santavirta S, Honkanen R. Outcome of sports injuries treated in a casualty department. $\mathrm{Br} J$ Sports Med 1985; 19(2): 103-6.

4 General Household Survey. Office of Population Census Studies. London: HMSO, 1985: 186-207.

5 Lindsay KW, McLatchie G, Jennet B. Serious head injury in sport. Br Med J 1980; 281: 789-91.

6 Reid DC, Saboe L. Spine fractures in winter sports. Sports Med 1989; 7: 393-9.

7 Elman MJ. Racket-sports ocular injuries. Arch Ophthalmol 1986; 104: 1453-4.

8 Strahlman E, Sommer A. The epidiomology of sports-related ocular trauma. Int Ophthalmol Clin 1988; 28(3): 199-202. 